\title{
The Impact of Financial Development on Economic Growth as Countries Develop Financially and Economically: WAEMU Countries Case
}

\author{
Daouda Coulibaly \\ Correspondence: Daouda Coulibaly, Department of Economics, Peleforo Gon Coulibaly University, Korhogo, Ivory \\ Coast.
}

\author{
Received: July 18, 2018 \\ Accepted: August 20, 2018 \\ Available online: August 31, 2018 \\ doi:10.11114/aef.v5i5.3588 \\ URL: https://doi.org/10.11114/aef.v5i5.3588
}

\begin{abstract}
We analyse financial development's impact on real gross domestic product per capita in seven West African Economic and Monetary Union (WAEMU) countries from 1970 to 2014. We assume that income and financial development process converge to USA, France and Japan's levels respectively. An analysis of the unit root and cointegration tests revealed non-stationary and cointegrated series. Estimates are based on the Dynamic Seemingly Unrelated Regression method (DSUR). Our study shows that, (i) the effect of financial development on real per capita GDP improves in WAEMU countries as the latter converge financially to their respective levels in USA, France and Japan; (ii) the effect of financial development on real GDP per capita decreases in the WAEMU countries as they grow economically to reach USA, France and Japan's income levels; (iii) the degree of the effect of financial development on real per capita GDP in the case of financial systems is stronger than that of the convergence of income.
\end{abstract}

Keywords: financial development, solow model, growth, panel cointegration, dynamic seemingly unrelated regression

JEL Classification: C23, G21, O40.

\section{Introduction}

The contribution of financial development to economic growth has long been the subject of theoretical controversy. Several studies have found a positive link between financial development and economic growth. These studies show that financial system affects positively economic growth through the financing of technological innovation (Schumpeter, 1911), a better allocation of savings to the most productive investments (King \& Levine, 1993), risks diversification (Greenwood \& Jovanovic, 1990) and an increase in the marginal productivity of investment (Pagano, 1993). While, other authors argue that financial system instead of accelerating economic growth tends to reduce it. By improving the allocation of resources and return on savings, financial development can reduce saving rate. If large externalities are associated with saving and investment, then financial development slows down long-run growth (Beck \& Levine, 2004). In addition, the management of information problems in credit markets by banks can lead to the situation of credit rationing and consequently results in a negative financial development effect on economic growth (Bencivenga \& Smith, 1993; Guillard \& Rajhi, 1993).

Another theoretical controversy is the role of financial structure in growth. That issue raises the following question: which is the vector of growth - banks or financial market? Or do they both contribute to the economic growth? Four theories fuel the debate about the relationship between financial structure and growth. The first argues that banking system is more efficient than financial market in financing economy. For the second theory, financial market predominates banks. Boyd and Smith (1998) and Aka (2005) find that the effect of banks on growth is stronger in developing countries, whereas in developed countries the effect of financial market is predominant. The third view states that financial services offered by financial system as a whole (banks and financial market) to the economy are important for improving growth. The last view, called theory of law and finance, considers finance as a set of contracts governed by legal rights and enforcement mechanisms. Thus, the smooth running of the legal system improves contract execution and facilitates both the operations of financial intermediaries and markets. It therefore enhances the efficient allocation of resources and economic growth. Luintel, Khan, Arestis, and Theodoridis (2008) partially verify Boyd and Smith's (1998) assumption that the financial market is becoming more important as economies grow. On the other hand, Beck and Levine (2004) and Levine (2002) fail to identify specifically the financial institution that generates growth, although financial system as a whole (banks and financial market) improves significantly economic growth. King and 
Levine (1993) predict a decrease in the impact of financial development on growth as countries grow and become richer. Luintel et al. (2008) have assessed the role of financial development on economic growth when countries become economically and financially developed and their economic and financial structures go up. They show that the effect of financial development on economic growth as countries develop financially and economically is variable and specific to each economy. This study provides an interesting analytical framework for understanding the role of financial development on economic growth in low- and middle-income countries in their process of growth towards the levels of economic and financial development of richer countries.

The objective of this paper is to analyse not only the impact of financial development on growth but also to examine the influence of financial development on growth as the economies of the WAEMU countries develop financially and economically to the respective levels of rich countries. To do this, we use new financial development indicators constructed according to the technique of Luintel et al. (2008) with the USA, France and Japan as reference countries. These indicators greatly help to determine financial development behavior with respect to economic growth when countries develop economically and financially. This has not yet been tested to our knowledge of the WAEMU countries. We chose these three economies because the USA is the world leading economic power with the highest level of economic and financial development. France, the colonising country, maintains historical relations with the WAEMU countries. It is therefore the first economic and financial partner of these countries and it is quite natural to take it into account in this study. Japan has a banking-oriented financial system like that of the WAEMU countries. We do not intend to compare the WAEMU countries to the level of USA, France or Japan nor to test whether or not they converge to them. But we want to determine the role of financial development on economic growth when economies and financial systems develop and tend towards the respective levels of developed countries.

The rest of the article is organised as follows: Section 2 presents a brief review of the empirical literature between financial development and growth. Section 3 describes the model. The results of the estimates are analysed in section 4 and we end with the conclusion.

\section{Literature Review}

The empirical impact of financial development on economic growth is not a priori defined. Using private credit

(\% GDP) as a financial indicator, De Gregorio and Guidotti (1995) find a strong negative and significant correlation between financial liberalisation and economic growth with panel data from 1950 to 1985 for twelve Latin American countries. Hay (2000) finds a similar result from a sample of panel data from twelve countries (six developed countries and six developing countries) over the period 1970-1996 with domestic credit to GDP and domestic credit to bank deposits as financial indicators. Using time series, Adusei (2012) also finds a negative effect of financial development on economic growth; in this study financial development reduces significantly per capita GDP both in the short run and in the long run. On the other hand, the estimation of a cointegrated panel by the FMOLS method allowed Christopoulos and Tsionas (2004) to show that financial development is actively involved in promoting economic growth. Rachdi and Mbarek (2011), using the same estimation technique and generalised method of moments, also support the positive effects of financial development on economic growth in four countries in the Middle East and North Africa, and six countries in Organisation for Economic Co-operation and Development (OECD). Khadraoui and Smida (2012) and Bist (2018) come to similar conclusions. With time series, Rao, Tamazian, Singh, and Vadlamannati (2008), Araç and Özcan (2014) also find a positive impact of financial development on long-run economic growth. The former use the Fully Modified Ordinary Least Squares (FMOLS) method from Phillips and Hansen (1990) while the latter use the Vector Error Correction Model (VECM) approach.

As for Loayza and Ranciere (2005), they argue that financial intermediation (private credit as a percentage of GDP) affects positively and significantly economic growth in the long run, but the effect is negative and significant in the short run. Different aspects of the financial development process (financial deepening and financial fragility) would explain these contradictory results. Indeed, financial deepening increases significantly economic growth while the financial fragility captured by financial volatility and bank crises deteriorates significantly economic growth. The total effect of financial liberalisation and financial intermediation on economic growth could be a combination of these effects where the relative influence of financial deepening and financial fragility would depend on the level of financial development of each country. Karlsson and Mansson (2015) find similar results in the case of 10 Asian economies from 1971 to 2013. Some authors find a non-significant effect of financial development on economic growth. This is the case for example of Hermes and Lensik (2005) and Esso (2005). Hermes and Lensik (2005) find a non-significant negative effect of the private sector credit to GDP on the per capita GDP growth rate with panel data from twenty five emerging countries. The results obtained by Esso (2005) show an indifference of economic growth to various financial indicators in the WAEMU countries from 1960 to 2002.

Levine (2002) analyses the impact of financial structure (banking and financial market) on economic growth in a cross-sectional study of a sample of 48 countries from 1980 to 1995 . He finds that the indicator of financial structure 
(Banking and financial market) does not explain significantly growth while indicators of overall financial development impact positively and significantly long run growth. By the same token, Beck and Levine (2004) argue that financial system as a whole (banks and financial market) improves significantly economic growth, but they fail to identify specifically the financial institution that generates growth. Luintel et al. (2008) partially verify Boyd and Smith's (1998) hypothesis which not only posits that banks-dominated financial systems are more favorable to economic growth and development when countries are at low levels of economic development, but also suggests that as countries develop financial market becomes more active. Indeed, from a sample of 14 countries in a time series study from 1978 to 2005 , the results show that six countries verify the hypothesis of Boyd and Smith, three countries invalidate it and the others remain indifferent. In addition, Luintel et al. (2008) also analysed the impact of financial development on growth when economies develop financially and economically. When countries develop financially the influence of financial development on growth is reduced in five countries and increases in four countries. In the other countries, the effect is not significant. When countries develop economically the impact of financial development on growth increases in five countries and declines in four countries and the effect is not significant in the others. Caporale, Rault, Sova, and Sova (2009) examine the relationship between financial development and growth in 10 new European Union member states over the period 1994-2007. They show that financial market is underdeveloped in these countries and therefore its contribution to economic growth is limited because of a lack of financial deepening. On the other hand, they find that a more efficient banking sector is accelerating growth. Lipovina-Bozovic and Smolovic (2016) assert that economic development is positively influenced by general financial development and the efficiency of the banking sector. Karagiannis and Kvedaras (2016) show that financial structure plays a central role in the relationship between financial development and economic growth. They conclude that bank credit to households and outstanding debt securities to financial corporations impact negatively and significantly economic growth, whereas credit to non-financial firms and stock markets act positively on economic growth.

Aka (2005) shows that there is an optimum threshold of structure from which financial intermediation less dynamises economic growth. Financial intermediation further stimulates economic growth in developing countries below the optimal threshold. Beyond the optimal threshold where developed countries have developed financial markets, financial intermediation less increases growth. This reinforces the work of De Gregorio and Guidotti (1995) which indicates that financial liberalisation is highly positively correlated with growth rate in low- and middle-income countries while it has no effect on the growth rate of high-income countries. Panizza (2012) figures the optimal threshold of $110 \%$ of the private sector credit to GDP. Indeed, according to the author, the effect of financial development on economic growth becomes negative, if the private credit rate reaches $110 \%$. This could be explained by the increased macroeconomic volatility caused by finance. In the context of European Union and Euro area, Karagiannis and Kvedaras (2016) find that the peak of the positive impact of bank credit on economic growth is close to 50\% of the GDP in the case of substantial share of credit to households and $65 \%$ of the GDP if all credit were directed towards non-financial corporations.

\section{Econometric Model}

To determine the impact of financial development on economic growth we use the Rao et al. (2008) model which is a modified production function of Solow (1956) with constant returns to scale and of technical progress neutral in the sense of Hicks,

$$
y_{t}=A_{t} k_{t}^{\alpha}, \quad 0<\alpha<1
$$

with $y_{t}$, the product per worker, $A_{t}$ the stock of technology and $k_{t}$, the capital per worker.

The technical progress which grows at an exponential rate $g$ over time is defined as:

$$
A_{t}=A_{0} e^{g t}
$$

where $A_{0}$ is the initial stock of knowledge and $\mathrm{t}$ is the time index.

Rao et al. (2008) assume that $A_{t}$ is a function of financial development $\left(\mathrm{FD}_{\mathrm{t}}\right)$ and time, that is,

$$
A_{t}=f\left(t, F D_{t}\right), f_{t} \text { and } F D_{t}>0
$$

Equation (3) is again written as follows

$$
A_{t}=A_{0} e^{g t} F D_{t}^{\beta}
$$

Replacing equation (4) in equation (1), we obtain the following equation of product per worker.

$$
y_{t}=\left(A_{0} e^{g t} F D_{t}^{\beta}\right) k_{t}^{\alpha}
$$

The linearised form of equation (5) to which we add the error term gives equation (6):

$$
L y_{t}=L A_{0}+g t+\beta L F D_{t}+\alpha L k_{t}+u_{t}
$$

where $\mathrm{L}$ is the symbol of the natural logarithm. 
Rao et al. (2008) conducted a time series study. For our part, we consider a panel data approach. As a result, equation (6) becomes

$$
L y_{i t}=L A_{0 i}+g_{i} t+\beta_{i} L F D_{i t}+\alpha_{i} L k_{i t}+u_{i t}
$$

Let us increase the equation (7) of traditional determinants of growth materialised by the variable $\mathrm{X}_{\mathrm{t}}$ :

$$
L y_{i t}=L A_{0 i}+g_{i} t+\beta_{i} L F D_{i t}+\alpha_{i} L k_{i t}+\gamma_{i} L X_{i t}+u_{i t}
$$

In order to analyse the role of financial development convergence in the process of economic growth, we based our analysis, as Luintel et al. (2008) did, on the interactive variables by taking the income level and financial development level of the USA, France and Japan as a benchmark. Considering, for example, the USA GDP per capita level, model (8) can be written as follows:

$$
L y_{i t}=L A_{0 i}+g_{i} t+\beta_{i} L F D_{i t}+\alpha_{i} L k_{i t}+\gamma_{i} L X_{i t}+\mu_{1 i} L F D Y C_{i t}+u_{1 i t}
$$

with FDYC the multiplicative variable of FD and $Y C$ where $Y C=(Y U S-y)$ represents the convergence of real GDP per capita of any country to that of the USA noted YUS. If $\mu_{1}$ is positive and significant, this implies that the impact of financial development increases during the income convergence process. On the contrary, the impact of financial development on growth will decrease as countries develop if $\mu_{1}$ is significantly less than zero. Using the financial development convergence of the countries under study compared to that of the USA, we can write the equation below:

$$
L y_{i t}=L A_{0 i}+g_{i} t+\beta_{i} L F D_{i t}+\alpha_{i} L k_{i t}+\gamma_{i} L X_{i t}+\mu_{2 i} L F D F D C_{i t}+u_{2 i t}
$$

where FDC measures the convergence of financial development of a country to that of the USA calculated as FDC = FDUS -FD and FDFDC is the multiplication of FD and FDC. If $\mu_{2}$ is significant and positive, the effect of financial development on growth increases with the process of its convergence to that of the USA. The opposite effect is observed if $\mu_{2}$ is significant and less than zero. Thus we are interested in the significance of the coefficients $\mu_{1}$ and $\mu_{2}$, rather than their sign. The interactive variables of convergence with reference to France and Japan are constructed in the same way as in the case of the USA.

\section{Estimation Results}

\subsection{Data Analysis}

Data come from two sources: The financial variables are taken from the DataMarket's web site. The financial development indicators selected in this study are liquid liabilities to GDP (ll), bank deposits as a percentage of GDP (bad) and the ratio of credit to the private sector to GDP (cps). Real variables are real GDP per capita (y), capital stock per capita (k) and government expenditure (gouv). They come from the Penn World Table database (PWT 9.0). We divided real GDP and capital stock by total population in order to obtain real GDP per capita and capital stock per capita, respectively. For more details about data source, see Appendix. All variables are expressed in logarithm which is denoted by the letter "L". Using the selected financial indicators, Lcps, Lll and Lbad, the income convergence and financial system convergence variables are respectively Lcpsyc, Lllyc, Lbadyc, and Lcpsc, Lllc and Lbadc. In the rest of the document, the following codes USA, FRA and JPN will refer respectively to the USA, France and Japan. Data refer to WAEMU countries with the exception of Guinea-Bissau where the series of variables of interest contain many missing data. The study period goes from 1970 to 2014.

Table 2. Descriptive statistics and correlations, panel data (1970-2014)

\begin{tabular}{lllllll}
\hline & Ly & Lk & Lgouv & Lcps & Lll & Lbad \\
\hline Mean & 7.256 & 7.797 & 0.147 & 0.163 & 0.209 & 0.141 \\
Maximum & 8.407 & 8.963 & 0.232 & 0.353 & 0.377 & 0.324 \\
Minimum & 6.466 & 5.653 & 0.038 & 0.032 & 0.067 & 0.030 \\
Standard Deviation & 0.445 & 0.709 & 0.033 & 0.072 & 0.062 & 0.058 \\
Nobs & 315 & 315 & 315 & 315 & 315 & 315 \\
Correlations & 1.000 & & & & & \\
Ly & 0.485 & 1.000 & & & & \\
Lk & $(0.000)$ & & & & \\
Lgouv & -0.051 & 0.082 & 1.000 & & & \\
Lcps & $(0.365)$ & $(0.145)$ & & & \\
LL & 0.575 & 0.125 & -0.009 & 1.000 & & \\
& $(0.000)$ & $(0.027)$ & $(0.880)$ & & & \\
Lbad & 0.502 & 0.326 & -0.059 & 0.609 & 1.000 & \\
& $(0.000)$ & $(0.000)$ & $(0.295)$ & $(0.000)$ & & \\
& 0.509 & 0.471 & 0.013 & 0.579 & 0.954 & 1.000 \\
& $(0.000)$ & $(0.000)$ & $(0.814)$ & $(0.000)$ & $(0.000)$ & \\
\hline
\end{tabular}

Note: P-values are in brackets 
Table 2 presents descriptive statistics and correlations. The highest average value is 7.797 for the variable Lk and the lowest average value is 0.030 for bank deposits (Lbad). Since variables are in logarithm, then this gap between the two extreme average values is acceptable as it is shown by the standard deviations. The lower part of Table 2 first summarises the correlation between different regressors, then it also sums up the one between explanatory variables and regressand. All correlations are significant at 5\% significance level except for the link between Lgouv and the variables Ly, Lk, Lll, Lcps and Lbad. The correlation between real per capita GDP (Ly) and explanatory variables is positive except Lgouv correlation that is negative. It ranges from -0.051 for government spending to 0.58 for credit to private sector. All financial development indicators are significantly and positively correlated with real GDP per capita. This conclusion is shared by many empirical works (King \& Levine, 1993; Beck, Levine, \& Loayza, 2000; Ang \& McKibbin, 2005; Loayza \& Ranciere, 2005; Keho, 2005; Liang \& Teng, 2006; Lakštutienè, 2008; Araç \& Özcan, 2014).

With respect to the binding among regressors, we observe both positive and negative linear associations between regressors. Aside from the low negative association between Lgouv and the variables Lcps and Lll, all other correlations are positive. Apart from linkage between liquid liabilities and bank deposits where correlation is greater than 0.6 all other correlations are less than or equal to 0.6. Strong connections between indicators of financial development are inconsequential for estimation in the sense that these variables are used separately in regressions. In sum, we can say that there is no multicollinearity in view of the weak correlations between regressors.

\subsection{Unit Root Tests}

The order of integration of series is carried out by the tests of Maddala and Wu (1999), Im, Pesaran and Shin (2003) and Bai and Carrion-i-Silvestre (2009). Maddala and Wu test and Im et al. test are respectively denominated MW and IPS. These two tests assume individual independence and the lags used in different regressions are chosen automatically according to the Schwarz criterion. Bai and Carrion-i-Silvestre (2009) panel unit root tests pool modified Sargan-Bhargava (MSB) tests for individual series, taking into account structural breaks and common factors effects. Structural changes are assumed heterogeneous across individuals. Common factors capture the comovement of economic time series as well as cross-section correlation (Bai \& Carrion-i-Silvestre, 2009, p479). All those tests are conducted with individual effects and linear trend in level and with individual effects (i.e. only the constant) in the first difference. The results are summarised in Table 3 and Table 4.

In level, the first generation tests (MW and IPS) with the significance level of 5\% reject the null hypothesis of unit root for five variables. These variables are: Lgouv, Lllyc_jpn, Lbadyc_usa, Lbadyc_fra and Lbadyc_jpn. For all the other variables, the two tests accept the null hypothesis of unit root at the 5\% level. In general, Bai and Carrion-i-Silvestre (2009) tests indicate non-stationary series at the 5\% level. However, the Pm test shows that the Lll and Lbad series are stationary. The P test leads to the same conclusion for the Lbad variable. Bai and Carrion-i-Silvestre (2009) show, however, that when structural breaks affect the trend the statistics $\mathrm{Z}, \mathrm{Pm} *$ and $\mathrm{P} *$ have better performance than the other statistics in terms of empirical size. But in the case the breaks only affect the mean it is the $\mathrm{Z}$ statistics that has the most powerful empirical power. The results of these three tests clearly show that we cannot reject the null hypothesis of unit root at the 5\% level for all variables. In the first difference, all series are stationary at the 5\% level whatever test we used. From the results of the tests contained in Table 4, especially the Z, Pm* and $\mathrm{P} *$ tests, we can say that the series are integrated from order 1 to the $5 \%$ level. In order to avoid the problem of spurious regressions, we have to check whether there is a long-run relationship between the variables I (1), that is to perform cointegration tests. 
Table 3. First generation unit roots tests results

\begin{tabular}{|c|c|c|c|c|}
\hline & \multicolumn{2}{|c|}{ Level : trend and constant } & \multicolumn{2}{|c|}{ First difference : constant } \\
\hline & IPS & MW & IPS & MW \\
\hline Ly & 0.480 & 13.557 & $-14.954 * * *$ & $184.533 * * *$ \\
\hline $\mathrm{Lk}$ & 0.354 & 10.454 & $-3.582 * * *$ & $37.152 * * *$ \\
\hline Lgouv & $-1.972 * *$ & $26.180 * *$ & & \\
\hline Lcps & 1.051 & 8.274 & $-10.716 * * *$ & $127.578 * * *$ \\
\hline Lcpsyc_usa & 0.307 & 8.997 & $-13.444 * * *$ & $162.995 * * *$ \\
\hline Lcpsyc_fra & -0.019 & 10.543 & $-12.994 * * *$ & $156.656 * * *$ \\
\hline Lcpsyc_jpn & -0.553 & 13.757 & $-12.704 * * *$ & $152.854 * * *$ \\
\hline Lcpsc_usa & 3.158 & 2.598 & $-14.157 * * *$ & $172.732 * * *$ \\
\hline Lcpsc_fra & -1.096 & 19.620 & $-23.743 * * *$ & $282.106 * * *$ \\
\hline Lcpsc_jpn & 0.279 & 10.188 & $-13.424 * * *$ & $163.052 * * *$ \\
\hline Lll & 1.754 & 7.606 & $-11.284 * * *$ & $133.269 * * *$ \\
\hline Lllyc_usa & -1.182 & 20.145 & $-10.896 * * *$ & $128.424 * * *$ \\
\hline Lllyc fra & $-1.488 *$ & $21.887^{*}$ & $-10.309 * * *$ & $119.852 * * *$ \\
\hline Lllyc ipn & $-1.916 * *$ & $25.431 * *$ & & \\
\hline Lllc_usa & 0.043 & 11.107 & $-9.707 * * *$ & $112.197 * * *$ \\
\hline Lllc_fra & 4.360 & 0.810 & $-7.276^{* * *}$ & $78.331 * * *$ \\
\hline Lllc_jpn & -0.981 & 20.561 & $-11.608 * * *$ & $139.281 * * *$ \\
\hline Lbad & 2.411 & 4.822 & $-10.293 * * *$ & $119.312 * * *$ \\
\hline Lbadyc_usa & $-2.481 * * *$ & $30.404 * * *$ & & \\
\hline Lbadyc_fra & $-2.833 * * *$ & $32.990 * * *$ & & \\
\hline Lbadyc_jpn & $-1.922 * *$ & $24.818 * *$ & & \\
\hline Lbadc_usa & 3.416 & 2.136 & $-7.273 * * *$ & $78.103 * * *$ \\
\hline Lbadc_fra & 2.795 & 2.572 & $-9.173 * * *$ & $103.025^{* * *}$ \\
\hline Lbadc_ipn & 2.847 & 4.070 & $-9.666 * * *$ & $110.198 * * *$ \\
\hline
\end{tabular}

Note: IPS and MW are the Im, Pesaran and Shin t-test and Maddala and Wu $\chi^{2}$ test for a unit root. The critical values for MW test are 29.14, 23.68 and 21.06 at $1 \%, 5 \%$ and $10 \%$ statistical levels, respectively. IPS test critical values are $2.326,-1.645$ and -1.282 at $1 \%, 5 \%$ and $10 \%$ statistical levels, respectively. $* * *, * *$ and $*$ denote rejection of the null hypothesis of unit roots at $1 \%, 5 \%$ and $10 \%$ levels respectively.

Table 4: Bai and Carrion-i-Silvestre (2009) panel unit root tests

\begin{tabular}{|c|c|c|c|c|c|c|c|c|c|}
\hline & \multicolumn{6}{|c|}{ Level } & \multicolumn{3}{|c|}{ First Difference } \\
\hline & \multicolumn{6}{|c|}{ Break in the trend } & \multicolumn{3}{|c|}{ Break in the mean } \\
\hline & $\mathrm{Z}$ & $\mathrm{Pm}$ & $\mathrm{P}$ & $Z^{*}$ & Pm* & $\mathrm{P}^{*}$ & $\mathrm{Z}$ & $\mathrm{Pm}$ & $\mathrm{P}$ \\
\hline Ly & -0.33 & -0.03 & 13.83 & -0.50 & 0.20 & 15.05 & $-1.94 * *$ & $10.40 * * *$ & $69.02 * * *$ \\
\hline $\mathrm{Lk}$ & 0.46 & -0.50 & 11.34 & 1.63 & -1.42 & 6.49 & $-1.74 * *$ & $5.42 * * *$ & $42.67 * * *$ \\
\hline Lgouv & 1.85 & -1.32 & 7.04 & 10.31 & -1.32 & 7.04 & $-1.57 *$ & $2.12 * *$ & $25.21 * *$ \\
\hline Lcps & -0.56 & -0.11 & 13.40 & -0.77 & -0.49 & 11.43 & $-2.01 * *$ & $7.12 * * *$ & $51.68 * * *$ \\
\hline Lcpsyc usa & 0.36 & -0.55 & 11.12 & 0.74 & -1.18 & 7.78 & $-2.04 * *$ & $6.92 * * *$ & $50.64 * * *$ \\
\hline Lcpsyc fra & -0.04 & -0.13 & 13.30 & 0.40 & -1.06 & 8.38 & $-2.00 * *$ & $5.51 * * *$ & $43.13 * * *$ \\
\hline Lcpsyc_jpn & -1.17 & 0.74 & 17.91 & -0.35 & 0.13 & 14.66 & $-2.04 * *$ & $7.17 * * *$ & $51.94 * * *$ \\
\hline Lcpsc_usa & -0.61 & -0.13 & 13.32 & -0.61 & -0.13 & 13.32 & $-2.03 * *$ & $8.84 * * *$ & $60.80 * * *$ \\
\hline Lcpsc_fra & 0.24 & -0.44 & 11.70 & 0.24 & -0.44 & 11.70 & $-2.11 * *$ & $11.31 * * *$ & $73.85^{* * *}$ \\
\hline Lcpsc ipn & -1.13 & 0.84 & 18.46 & -0.96 & 0.60 & 17.20 & $-1.88 * *$ & $9.53 * * *$ & $64.44 * * *$ \\
\hline Lll & $-1.60 *$ & $1.75 * *$ & $23.27 *$ & -0.95 & 0.95 & 19.01 & $-2.11 * *$ & $9.73 * * *$ & $65.47 * * *$ \\
\hline Lllyc_usa & -0.83 & 0.32 & 15.70 & -0.48 & 0.51 & 16.70 & $-2.16 * *$ & $12.68 * * *$ & $81.12 * * *$ \\
\hline Lllyc_fra & -0.85 & 0.79 & 18.20 & -0.15 & 0.50 & 16.67 & $-1.88 * *$ & $5.03 * * *$ & $40.63 * * *$ \\
\hline Lllyc_jpn & 0.21 & -1.07 & 8.32 & 0.03 & -0.87 & 9.42 & $-2.12 * *$ & $11.01 * * *$ & $72.26 * * *$ \\
\hline Lllc_usa & -0.69 & -0.60 & 10.83 & -0.81 & -0.59 & 10.86 & $-1.92 * *$ & $4.73 * * *$ & $39.03 * * *$ \\
\hline Lllc_fra & 2.64 & -0.87 & 9.40 & 7.72 & -1.36 & 6.82 & $-1.95 * *$ & $5.14 * * *$ & $41.18 * * *$ \\
\hline Lllc_jpn & -1.15 & 0.84 & 18.44 & 0.21 & 0.58 & 17.07 & $-1.93 * *$ & $5.73 * * *$ & $44.32 * * *$ \\
\hline Lbad & -1.26 & $2.31 * *$ & $26.21 * *$ & -1.12 & 0.46 & 16.44 & $-2.13 * *$ & $11.30 * * *$ & $73.79 * * *$ \\
\hline Lbadyc_usa & -0.65 & 0.05 & 14.29 & -0.03 & 0.06 & 14.33 & $-1.99 * *$ & $8.21 * * *$ & $57.48 * * *$ \\
\hline Lbadyc_fra & -0.32 & -0.11 & 13.43 & 0.05 & 0.05 & 14.27 & $-1.90 * *$ & $4.68 * * *$ & $38.79 * * *$ \\
\hline Lbadyc_jpn & -0.50 & -0.68 & 10.42 & 0.33 & -0.82 & 9.68 & $-1.99 * *$ & $8.38 * * *$ & $58.32 * * *$ \\
\hline Lbadc usa & 0.42 & -0.44 & 11.70 & 0.25 & $-0.5 \overline{5}$ & 11.10 & $-1.98 * *$ & $6.59 * * *$ & $48.89 * * *$ \\
\hline Lbadc fra & -0.68 & -0.37 & 12.06 & 0.11 & -0.12 & 13.38 & $-2.19 * *$ & $17.81 * * *$ & $108.25 * * *$ \\
\hline Lbadc_ipn & -0.61 & -0.45 & 11.64 & 0.33 & -1.05 & 8.44 & $-2.09 * *$ & $9.90 * * *$ & $66.39 * * *$ \\
\hline
\end{tabular}

Note: Z, Pm and P denote the test statistics developed by Bai and Carrion-i-Silvestre (2009). The critical values are: Z: $-2.33(1 \%),-1.65(5 \%)$ and -1.28 (10\%), Pm: $2.33(1 \%), 1.65(5 \%)$ and 1.28 (10\%), P: $29.14(1 \%), 23.68(5 \%)$ and $21.06(10 \%) . \mathrm{Z}^{*}, \mathrm{Pm}^{*}$, and $\mathrm{P}^{*}$ refer to the corresponding statistics obtained using the p-values of the simplied MSB statistics. $* * *, * *$ and $*$ denote rejection of the null hypothesis of unit roots at $1 \%, 5 \%$ and $10 \%$ levels respectively. Tests are conducted with a maximum of 2 structural breaks and a maximum of 4 common factors estimated with BIC method. 


\subsection{Cointegration Tests}

The analysis of cointegration is carried out by Pedroni's $(1999,2004)$ panel adf-statistic (P_adf) and group adf-statistic (G_adf) tests, and the $\phi_{N}$ and $\tau_{N}$ tests of Westerlund and Edgerton (2006). Rachdi and Mbarek (2011) argue that in the case of small samples, the G_adf test is the most robust. Westerlund and Edgerton (2006) consider both break and cross-section dependence in testing the cointegrating relation. All those tests are carried out with a maximum of 6 lags. The criterion of Hannan and Quinn (1979) is used to determine the optimal lag in the Pedroni tests. These tests are conducted by taking into account the constant and the linear trend. The breaks are considered both at the level of the constant and the slope in the Westerlund and Edgerton tests. The results are shown in Table 5. Regardless of the reference country and the test used, Pedroni's tests do not reject the hypothesis of no cointegration: all specifications accept the null hypothesis of no cointegration at the 5\% level except the equations of Lbadc_usa, Lbadc_fra, Lcredyc_jpn, Lcredc_jpn and Lllyc_jpn. The Westerlund and Edgerton tests support the cointegrating relation hypothesis but this is not true for all specifications when we consider the $\phi_{N}$ test in regime shift case. For example, Lcpsyc equations accept the null hypothesis of no cointegration at any conventional significance level for any reference country.

In a whole, the Westerlund and Edgerton (2006) tests with level shift or regime shift clearly state that there is a cointegration relationship in the data on hand. From an economic point of view, this means that there is a long-run relationship between the dependent variable and the explanatory variables. This result is contrary to the work of Esso (2005) but goes in the same direction to the conclusions of Christopoulos and Tsionas (2004), Rachdi and Mbarek (2011) and Bist (2018). The estimation of cointegrated panel data model requires the use of efficient estimation methods.

Table 5. Cointegration results

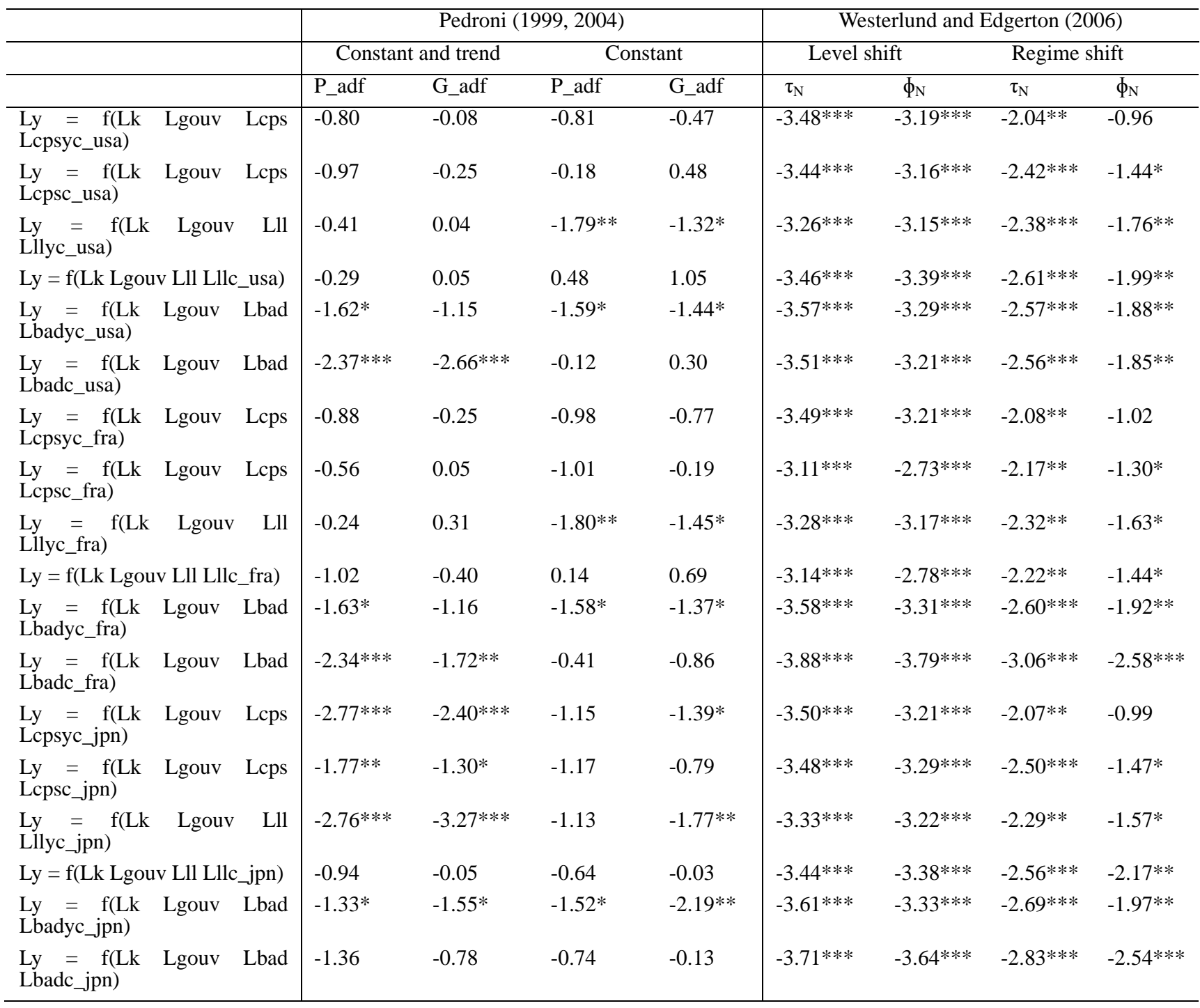


Note: For the tests of Westerlund and Edgerton (2006) we took a maximum of 2 common factors and the number of structural breaks is estimated automatically. ***, **, *, denote rejection of the null hypothesis of no cointegration for the $1 \%, 5 \%$ and $10 \%$ levels respectively. All statistics are compared to $-2.326,-1.645$ and -1.282 for respectively levels of $1 \%, 5 \%$ and $10 \%$. Trimming: 0.15

\subsection{Estimation of Long-Run Coefficients}

If the cointegration test confirms the long-run relationship between the endogenous and the regressors, then an efficient estimation method must be used. The estimation of a cointegrated panel model by the Ordinary Least Squares (OLS) method produces biased estimators (Pedroni, 2000; Kao \& Chiang, 2000). And the Generalised Method of Moment estimator is non-convergent when the dependent variable is not stationary (Hämäläinen \& Malinen, 2009). For this purpose, we use the Dynamic Seemingly Unrelated Regression (DSUR) method of Mark, Ogaki, and Sul (2005). That method is applicable only for panel data where the temporal dimension $(T)$ is greater than the number of cross sections (N). In the case of small samples, Mark et al. (2005) argue that the DSUR method offers a gain in efficiency over other estimators when one starts from a moderate dependency to a strong correlation of cross sections. Moreover, the authors demonstrate that the DSUR method yields significant efficiency gains over non-system methods such as Dynamic Ordinary Least Squares (DOLS) when a set of heterogeneous regressors enter into the regressions and when there is a correlation between the equilibrium errors of the different cointegrating equations.

Tables 6 to 8 present the estimation results per country of convergence. Fixed capital stock per capita (Lk) coefficient depends on the convergence indicator we used. The coefficient is negative and statistically insignificant in Lcpsyc equations whatever the country of convergence and in Lcpsc_jpn equation. In other equations fixed capital stock per capita has a statistically significant positive effect on real GDP per capita. As for government expenditures, they reduce economic growth in all specifications except the equation of Lbadc_fra, Lllc_jpn and Lbadyc_jpn, where the respective coefficients are $0.04,0.01$ and 0.03 . However we note that the impact is not statistically significant in several equations. This negative relation is confirmed by previous studies (Loayza \& Ranciere, 2005; Rachdi \& Mbarek, 2011).

The influence of financial development varies according to the indicator and the convergence variables we chose. Private credit rate and liquidity rate do not seem to be statistically significant for real GDP per capita. However bank deposits affects significantly economic growth, the effect is positive at the $1 \%$ level in the income convergence equations (Lbadyc) and negative at the $1 \%$ level in the financial system convergence equations (Lbadc). An explanation of the negative effect of financial development on growth in the WAEMU countries would be the banking crisis of the 1980s. This assertion is shared by Loayza and Ranciere (2005). The positive effect of financial development on growth is confirmed by previous analyses (De Gregorio \& Gudotti, 1995; Beck et al., 2000; Christopoulos \& Tsionas, 2004; Bist, 2018).

Let us now analyse the impact of financial development on growth through interactive variables of convergence. We first consider the situation of income convergence. At this level, we note that on average the effect of financial development on growth decreases as the income level of WAEMU countries converges to that of the USA, France and Japan. When we averaged the statistically significant coefficients we found that as the incomes of WAEMU countries converge towards those of the USA, France and Japan, the impact of financial development on economic growth is reduced by $0.01 \%, 0.06 \%$ and $0.08 \%$ respectively following a $1 \%$ increase in financial development. This result implies that the effect of financial development on growth is diminishing in the countries of the Union as the latter develop economically in order to reach the levels of the USA, France and Japan. However, in the case of the convergence of financial systems the impact of financial development on growth is improving. The average effect of financial development on growth is $0.30,0.69$ and 1.08 in USA, France and Japan respectively. It can be said that the effect of financial development on real GDP per capita increases in WAEMU countries when the financial system of the latter converges towards that of USA, France and Japan. 
Table 6. DSUR estimates with USA as reference country

Dependent variable: Ly

\begin{tabular}{|c|c|c|c|c|c|c|}
\hline Lk & $\begin{array}{l}-0.03^{*} \\
(-1.79)\end{array}$ & $\begin{array}{l}0.01 \\
(0.69)\end{array}$ & $\begin{array}{l}0.09 * * * \\
(4.04)\end{array}$ & $\begin{array}{l}0.03 \\
(1.35)\end{array}$ & $\begin{array}{l}0.10 * * * \\
(4.545)\end{array}$ & $\begin{array}{l}0.09 * * * \\
(4.68)\end{array}$ \\
\hline Lgouv & $\begin{array}{l}-0.08 \\
(-0.72)\end{array}$ & $\begin{array}{l}-0.16 \\
(1.49)\end{array}$ & $\begin{array}{l}-0.08 \\
(-0.81)\end{array}$ & $\begin{array}{l}-0.35^{* * * *} \\
(-3.30)\end{array}$ & $\begin{array}{l}-0.15 \\
(-1.71)\end{array}$ & $\begin{array}{l}-0.14 \\
(-1.66)\end{array}$ \\
\hline Lcps & $\begin{array}{l}-0.47 * * * \\
(-3.11)\end{array}$ & $\begin{array}{l}-0.08 \\
(-0.56)\end{array}$ & & & & \\
\hline Lcpsyc_usa & $\begin{array}{l}0.10 * * * \\
(4.52)\end{array}$ & & & & & \\
\hline Lcpsc_usa & & $\begin{array}{l}0.30 * * \\
(1.97)\end{array}$ & & & & \\
\hline Lll & & & $\begin{array}{l}0.25 \\
(1.00)\end{array}$ & $\begin{array}{l}-0.08 \\
(-0.53)\end{array}$ & & \\
\hline Lllyc_usa & & & $\begin{array}{l}-0.05 \\
(-1.22)\end{array}$ & & & \\
\hline Lllc_usa & & & & $\begin{array}{l}0.40 \\
(0.88)\end{array}$ & & \\
\hline Lbad & & & & & $\begin{array}{l}0.79 * * * \\
(3.97)\end{array}$ & $\begin{array}{l}-0.51 * * * \\
(-3.01)\end{array}$ \\
\hline Lbadyc_usa & & & & & $\begin{array}{l}-0.12 * * * \\
(-5.35)\end{array}$ & \\
\hline Lbadc_usa & & & & & & $\begin{array}{l}0.43 \\
(1.28)\end{array}$ \\
\hline
\end{tabular}

Note: T-statistics are presented in parentheses. $* * * * *$ and $*$ indicate statistical significance at the $1 \%, 5 \%$ and $10 \%$ levels, respectively. All DSUR estimations include individual constant and common time effect with 2 lags and leads.

Table 7. DSUR estimates with France as reference country

Dependent variable: Ly

\begin{tabular}{|c|c|c|c|c|c|c|}
\hline $\mathrm{Lk}$ & $\begin{array}{l}-0.05 * * * \\
(-281)\end{array}$ & $0.05 * *$ & $\begin{array}{l}0.06 * * * \\
(341)\end{array}$ & 0.00 & $0.06^{* * *}$ & $0.11 * * *$ \\
\hline Lgouv & $\begin{array}{l}-0.05 \\
(-0.47)\end{array}$ & $\begin{array}{l}-0.17 * \\
(-1.79)\end{array}$ & $\begin{array}{l}-0.092 \\
(-1.195)\end{array}$ & $\begin{array}{l}-0.39 * * * \\
(-3.45)\end{array}$ & $\begin{array}{l}-0.20^{*} \\
(-1.91)\end{array}$ & $\begin{array}{l}0.04 \\
(0.43)\end{array}$ \\
\hline Lcps & $\begin{array}{l}-0.21 \\
(-1.37)\end{array}$ & $\begin{array}{l}0.24 * * \\
(2.06)\end{array}$ & & & & \\
\hline Lcpsyc_fra & $\begin{array}{l}0.05^{* *} \\
(2.33)\end{array}$ & & & & & \\
\hline Lcpsc_fra & & $\begin{array}{l}-0.09 \\
(-0.43)\end{array}$ & & & & \\
\hline Lll & & & $\begin{array}{l}0.60 * * * \\
(3.26)\end{array}$ & $\begin{array}{l}0.01 \\
(0.14)\end{array}$ & & \\
\hline Lllyc_fra & & & $\begin{array}{l}-0.11 * * * \\
(-4.71)\end{array}$ & & & \\
\hline Lllc_fra & & & & $\begin{array}{l}0.42 \\
(1.69)\end{array}$ & & \\
\hline Lbad & & & & & $\begin{array}{l}0.74 * * * \\
(4.54)\end{array}$ & $\begin{array}{l}-0.49 * * * \\
(-3.48)\end{array}$ \\
\hline Lbadyc_fra & & & & & $\begin{array}{l}-0.11^{* * * *} \\
(-6.06)\end{array}$ & \\
\hline Lbadc_fra & & & & & & $\begin{array}{l}0.69 * * \\
(2.34)\end{array}$ \\
\hline
\end{tabular}

Note: T-statistics are presented in parentheses. $* * * * *$ and $*$ indicate statistical significance at the $1 \%, 5 \%$ and $10 \%$ levels, respectively. All DSUR estimations include individual constant and common time effect with 2 lags and leads. 
Table 8. DSUR estimates with Japan as reference country

Dependent variable: Ly

\begin{tabular}{|c|c|c|c|c|c|c|}
\hline Lk & $\begin{array}{l}-0.02 \\
(-1.18)\end{array}$ & $\begin{array}{l}-0.00 \\
(-0.20)\end{array}$ & $\begin{array}{l}0.07 * * * \\
(3.60)\end{array}$ & $\begin{array}{l}0.14 * * * \\
(6.90)\end{array}$ & $\begin{array}{l}0.06 * * * \\
(3.56)\end{array}$ & $\begin{array}{l}0.18 * * * \\
(10.59)\end{array}$ \\
\hline Lgouv & $\begin{array}{l}-0.13 \\
(-1.23)\end{array}$ & $\begin{array}{l}-0.31 * * * \\
(-3.27)\end{array}$ & $\begin{array}{l}-0.21 * * \\
(-1.97)\end{array}$ & $\begin{array}{l}0.01 \\
(0.16)\end{array}$ & $\begin{array}{l}0.03 \\
(0.48)\end{array}$ & $\begin{array}{l}-0.03 \\
(-0.51)\end{array}$ \\
\hline Lcps & $\begin{array}{l}0.23 \\
(1.59)\end{array}$ & $\begin{array}{l}0.23 \\
(1.60)\end{array}$ & & & & \\
\hline Lcpsyc_jpn & $\begin{array}{l}-0.01 \\
(-0.45)\end{array}$ & & & & & \\
\hline Lcpsc_jpn & & $\begin{array}{l}-0.08 \\
(-0.73)\end{array}$ & & & & \\
\hline Lll & & & $\begin{array}{l}0.36 \\
(1.66)\end{array}$ & $\begin{array}{l}-2.24 * * * \\
(-9.36)\end{array}$ & & \\
\hline Lllyc_jpn & & & $\begin{array}{l}-0.06^{*} \\
(-1.72)\end{array}$ & & & \\
\hline Lllc_jpn & & & & $\begin{array}{l}1.56^{* * * *} \\
(8.74)\end{array}$ & & \\
\hline Lbad & & & & & $\begin{array}{l}0.39 * * * \\
(3.70)\end{array}$ & $\begin{array}{l}-1.16 * * * \\
(-6.93)\end{array}$ \\
\hline Lbadyc_jpn & & & & & $\begin{array}{l}-0.08 * * * \\
(-6.82)\end{array}$ & \\
\hline Lbadc_jpn & & & & & & $\begin{array}{l}0.59 * * * \\
(4.53)\end{array}$ \\
\hline
\end{tabular}

Note: T-statistics are presented in parentheses. $* * * * *$ and $*$ indicate statistical significance at the $1 \%, 5 \%$ and $10 \%$ levels, respectively. All DSUR estimations include individual constant and common time effect with 2 lags and leads.

In sum, the results indicate that the overall effect of financial development on growth depends on the convergence variable. The results also show a strong impact of financial development in the case of convergence of financial systems relative to the convergence of incomes. In fact, these results can be explained as follows: The negative effect through the convergence of income can be explained in two ways: first, it may be due to a decrease in the overall effect of financial development on economic growth as countries develop economically as emphasized by King and Levine (1993). Secondly, this could be due to the large gap between the level of development of WAEMU countries and that of countries like the USA, France and Japan. As highlighted by Aghion, Howitt, and Mayer-Foulkes (2005), financial development has a positive effect on the steady-state level of per-capita GDP relative to the frontier in a country that converges to the frontier growth rate. GDP per capita of WAEMU countries does not converge towards those of the USA, France or Japan. A comparison between these two levels of development is certainly not appropriate. On the other hand, the positive effect of financial development through the convergence of the financial system can be justified by the increased and rapid integration of financial systems. We know that WAEMU area is dominated by foreign banks. In 2016 , for example, the West African Monetary Union Banking Commission Report notes that half of the banks were international banks, or 66 banks out of a total of 131. It is shown that the introduction of foreign banks improves the efficiency of the domestic financial system, which in turn enhances economic growth (Levine, 2001). Many studies show that financial integration acts positively on economic growth through its indirect effect on financial development (De Gregorio, 1999; Levine, 2001; Osada \& Saito, 2010; Mahajan \& Verma, 2015). According to Mahajan and Verma (2015), in the case of India, the change in economic growth due to international financial integration through financial development is approximately $8.63 \%$.

\section{Conclusion}

The main concern of this paper was to assess the impact of financial development on the economic growth of WAEMU countries. Specifically, we have tested the effect of financial development on growth as countries develop financially and economically and tend towards the respective levels of rich countries such as the USA, France and Japan. The production function of Solow (1956) modified by Rao et al. (2008) is used to determine the impact of financial development on growth. Estimated results indicate on the one hand that the effect of financial development on growth is declining in WAEMU countries as they grow economically to reach USA, France and Japan levels. On the other hand, the effect of financial development on growth is improving when the financial system of WAEMU countries converges to those of USA, France and Japan's levels. The results also show a strong impact of financial development in the case of convergence of financial systems relative to the convergence of incomes. WAEMU countries should take measures 
that will boost growth and increase incomes in order to accelerate the process of convergence of incomes and reduce the gap between WAEMU countries and developed countries. They will also improve the quality and performance of financial systems in order to accelerate the development and reinforce the integration of financial systems. Financial systems should therefore be better regulated to reduce or limit the negative effects that may result from financial integration. All this should be accompanied by macroeconomic discipline, good governance and the establishment of better institutions.

\section{Acknowledgements}

We would like to thank anonymous referees for useful suggestions to the improvement of the quality of this paper. We are also grateful to Donggyu Sul and Joakim Westerlund for providing the program code on their homepage. Donggyu Sul provided on his homepage the gauss program to implement DSUR estimation. Joakim Westerlund provided the gauss program of Westerlund and Edgerton (2006) cointegration tests.

\section{References}

Adusei, M. (2012). Financial Development and Economic Growth: Is Schumpeter Right? British Journal of Economics, Management \& Trade, 2(3), 265-278.

Aghion, P., Howitt, P., \& Mayer-Foulkes, D. (2005). The Effect of Financial Development on Convergence: Theory and Evidence. Quaterly Journal of Economics, 120(1), 173-222. https://doi.org/10.1162/qjec.2005.120.1.173

Aka, B. E. (2005). Le Rôle des Marchés de Capitaux dans la Croissance et le Développement Economiques (Thèse de Doctorat, Université d'Auvergne, Clermont-Ferrand I). Disponible sur https://tel.archives-ouvertes.fr/tel-00663447

Ang, J. B., \& McKibbin, J. W. (2005). Financial Liberalization, Financial Sector Development and Growth: Evidence from Malaysia. Brookings Discussion Papers in International Economics No. 168.

Araç, A., \& Özcan, K. S. (2014). The Causality between Financial Development and Economic Growth: The Case of Turkey. Journal of Economic Cooperation and Development, 35(3), 171-198.

Bai, J., \& Carrion-i-Silvestre, J. L. (2009). Structural Changes, Common Stochastic Trends, and Unit Roots in Panel Data. The Reviews of Economics Studies, 76(2), 471-501. https://doi.org/10.1111/j.1467-937X.2008.00530.x

Beck, T., \& Levine, R. (2004). Stock Markets, Banks, and Growth: Panel Evidence. Journal of Banking \& Finance, 28(3), 423-442. https://doi.org/10.1016/S0378-4266(02)00408-9

Beck, T., Levine, R., \& Loayza, N. (2000). Finance and the Sources of Growth. Journal of Financial Economics, 58(1-2), 261-300. https://doi.org/10.1016/S0304-405X(00)00072-6

Bencivenga, V. R., \& Smith, B. D. (1993). Some Consequences of Credit Rationing in an Endogenous Growth Model. Journal of Economic Dynamics and Control, 17(1-2), 97-122. https://doi.org/10.1016/S0165-1889(06)80006-0

Bist, P. J. (2018). Financial Development and Economic Growth: Evidence from a panel of 16 African and non-African low-income countries. Cogent Economics \& Finance, 6(1), 1449780, 1-17, https://doi.org/10.1080/23322039.2018.1449780

Boyd, J. H., \& Smith, B. D. (1998). The Evolution of Debt and Equity Markets in Economic Development. Economic Theory, 12(3), 512-560. https://doi.org/10.1007/s001990050234

Caporale, M. G., Rault, C., Sova, R., \& Sova, A. (2009). Financial Development and Economic Growth: Evidence from Ten New EU Members. Economics and Finance Working Paper Series No. 09-37, https://doi.org/10.2139/ssrn.1499786

Christopoulos, D. K., \& Tsionas, E. G. (2004). Financial Development and Economic Growth: Evidence from Panel Unit Root and Cointegration Tests. Journal of Development Economics, 73(1), 55-74. https://doi.org/10.1016/j.jdeveco.2003.03.002

De Gregorio, J. (1999). Financial Integration, Financial Development and Economic Growth. Estudios de Economia, 26(2), 137-161.

De Gregorio, J., \& Guidotti, P. (1995). Financial Development and Economic Growth. World Development, 23(3), 433-448. https://doi.org/10.1016/0305-750X(94)00132-I

Esso, L. J. (2005). Développement Financier, Croissance Economique et Inégalités de Revenu entre Pays de l’UEMOA. Bulletin de Politique Economique et Développement (BUPED) No. 111.

Feenstra, R. C., Inklaar, R., \& Timmer, M. P. (2015). The Next Generation of the Penn World Table. American Economic Review, 105(10), 3150-3182. https://doi.org/10.1257/aer.20130954

Greenwood, J., \& Jovanovic, B. (1990). Financial Development, Growth and the Distribution of Income. Journal of 
Political Economy, 98(5), 1076-1107. https://doi.org/10.1086/261720

Guillard, M., \& Rajhi, T. (1993). Croissance et Développement: Le Rôle des Rationnements Financiers. Revue Economique, 44(2), 229-255. https://doi.org/10.2307/3502240

Hämäläinen, P., \& Malinen, T. (2009). The Relationship Between Regional Value Added and Public Capital in Finland: What Do the New Panel Econometrics Techniques Tell Us? Helsinki Center of Economic Research Discussion Papers No. 256.

Hannan, E. J., \& Quinn, B. G. (1979). The Determination of the Order of an Autoregression. Journal of the Royal Statistical Society. Series B, 41(2), 190-195.

Hay, M. (2000, Juin). Banques et Croissance: Examen Critique et Analyse en Données de Panel. Papier présenté au XVII ${ }^{\text {èmes }}$ Journées Internationales d'Economie Monétaire et Bancaire, Lisbonne.

Hermes, N., \& Lensik, R. (2005). Does Financial Liberalization Influence Saving, Investment and Economic Growth? Evidence from 25 Emerging Market Economies, 1973-96. World Institute for Development Economics Research Paper No. 2005 / 69.

Im, K. S., Pesaran, M. H., \& Shin, Y. (2003). Testing for Unit Roots in Heterogeneous Panels. Journal of Econometrics, 115(1), 53-74. https://doi.org/10.1016/S0304-4076(03)00092-7

Kao, C., \& Chiang, M. H. (2000). On the Estimation and Inference of a Cointegrated Regression in Panel Data, in B. Baltagi (Ed), Nonstationary Panels, Panel Cointegration, and Dynamic Panels (vol. 15, pp. 179-222). Amsterdam: Elsevier. https://doi.org/10.1016/S0731-9053(00)15007-8

Karagiannis, S., \& Kvedars, V. (2016). Financial Development and Economic Growth. A European Perspective. JRC Science for Policy Report, European Commission, EUR 28324 EN.

Karlsson, K. H., \& Mansson, K. (2015). Revisiting the Nexus of the Financial Development and Economic Growth Wavelet Approach with a focus on Asian Economies. Working Paper No. 2015:37.

Keho, Y. (2005). Efficacité Macroéconomique du Crédit Bancaire en Côte d'Ivoire. Bulletin de Politique Economique et Développement (BUPED), No. 69.

Khadraoui, N., \& Smida, M. (2012). Financial Development and Economic Growth: Static and Dynamic Panel Data Analysis. International Journal of Economics and Finance, 4(5), 94-104. https://doi.org/10.5539/ijef.v4n5p94

King, R. G., \& Levine R. (1993). Finance and Growth: Schumpeter Might be Right. The Quarterly Journal of Economics, 108(3), 717-737. https://doi.org/10.2307/2118406

Lakštutiene, A. (2008). Correlation of the Indicators of the Financial System and Gross Domestic Product in European Union Countries. Economic of Engineering Decisions, 58(3), 7-18.

Levine, R. (2001). International Financial Liberalization and Economic Growth. Review of International Economics, 9(4), 688-702. https://doi.org/10.1111/1467-9396.00307

Levine, R. (2002). Bank-based or Market-based Financial Systems: Which is Better? NBER Working Paper No. 9138.

Liang, Q., \& Teng, J. (2006). Financial Development and Economic Growth: Evidence from China. China Economic Review, 17(4), 395-411. https://doi.org/10.1016/j.chieco.2005.09.003

Lipovina, B. M., \& Smolovic, C. J. (2016). Evidence on Economic Growth and Financial Development in Montenegro. Management, 11(4), 349-365.

Loayza, N., \& Ranciere, R. (2005). Financial Development, Financial Fragility, and Growth. IMF Working Paper No. 05/170. https://doi.org/10.5089/9781451861891.001

Luintel, K. B., Khan, M., Arestis, P., \& Theodoridis, K. (2008). Financial Structure and Economic Growth. Journal of Development Economics, 86(1), 181-200. https://doi.org/10.1016/j.jdeveco.2007.11.006

Maddala, G. S., \& Wu, S. (1999). A Comparative Study of Unit Root Tests with Panel Data and a New Simple Test. Oxford Bulletin of Economics and Statistics, 61(1), 631-652. https://doi.org/10.1111/1468-0084.61.s1.13

Mahajan, N., \& Verma, S. (2015). International Financial Integration and Economic Growth in India: An Empirical Investigation. Eurasian Journal of Business and Economics 2015, 8(16), 121-137. https://doi.org/10.17015/ejbe.2015.016.07

Mark, N. C., Ogaki, M., \& Sul, D. (2005). Dynamic Seemingly Unrelated Cointegrating Regressions. Review of Economic Studies, 72(3), 797-820. https://doi.org/10.1111/j.1467-937X.2005.00352.x

Osada, M., \& Saito, M. (2010). Financial Integration and Economic Growth: An Empirical Analysis Using International 
Panel Data from 1974-2007. Bank of Japan Working Paper Series No. 10-E-5.

Pagano, M. (1993). Financial Markets and Growth: An Overview. European Economic Review, 37(2-3), 613-622. https://doi.org/10.1016/0014-2921(93)90051-B

Panizza, U. (2012). Finance and Economic Development. International Development Policy, 3, 141-160. https://doi.org/10.1007/978-1-137-00357-7_10

Pedroni, P. (1999). Critical Values for Cointegration Tests in Heterogeneous Panels with Multiple Regressors. Oxford Bulletin of Economics and Statistics, 61(4), 653-670. https://doi.org/10.1111/1468-0084.61.s1.14

Pedroni, P. (2000). Fully Modified OLS for heterogeneous cointegrated panels, in B. Baltagi (Ed), Nonstationary Panels, Panel Cointegration, and Dynamic Panels (vol. 15, pp. 93-130). Amsterdam: Elsevier. https://doi.org/10.1016/S0731-9053(00)15004-2

Pedroni, P. (2004). Panel Cointegration: Asymptotic and Finite Sample Properties of Pooled Time Series Tests with an Application to the PPP Hypothesis. Econometric Theory, 20(3), 597-625. https://doi.org/10.1017/S0266466604203073

Phillips, P. C. B., \& Hansen, B. E. (1990). Statistical inference in instrumental variable regression with I (1) processes. Review of Economic Studies, 57(1), 99-125. https://doi.org/10.2307/2297545

Rachdi, H., \& Mbarek, H. B. (2011). The Causality between Financial Development and Economic Growth: Panel Data Cointegration and GMM System Approaches. International Journal of Economics and Finance, 3(1), 143-151. https://doi.org/10.5539/ijef.v3n1p143

Rao, B. B., Tamazian, A., Singh, R., \& Vadlamannati, K. C. (2008). Financial Development and the Rate of Growth of Output: An Alternative Approach. Munich Personal RePEc Archive Paper No. 8605.

Schumpeter, J. A. (1911). The Theory of Economic Development, Haward University Press, Cambridge.

Solow, R. (1956). A Contribution to the Theory of Economic Growth. Quarterly Journal of Economics, 70(1), 65-94. https://doi.org/10.2307/1884513

Union Monétaire Ouest Africaine. (2017). Rapport Annuel de la Commission Bancaire -2016.

Westerlund, J., \& Edgerton, D. (2006). Simple Tests for Cointegration in Dependent Panels with Structural Breaks. Working Paper No.13, Lund University Department of Economics.

\section{Appendix}

Table 1. Variables definition and Data sources

\begin{tabular}{l|l|l|l}
\hline Variables & Name & Log transformation & Source \\
\hline Ly & Real GDP per capita & Log(rgdpna/pop) & Penn World Table database 9.0 \\
\hline Lk & Capital stock per capita & $\log (\mathrm{ck} /$ pop $)$ & Penn World Table database 9.0 \\
\hline Lgouv & Government expenditures & $\log [1+(\mathrm{V}$ g/V_gdp $)]$ & Penn World Table database 9.0 \\
\hline Lcps & Private credit to GDP & $\log (1+\mathrm{cps})$ & www.datamarket.com/data/set \\
\hline Lll & Liquid liabilities to GDP & $\log (1+\mathrm{ll})$ & www.datamarket.com/data/set \\
\hline Lbad & Bank deposits to GDP & $\log (1+\mathrm{bad})$ & www.datamarket.com/data/set \\
\hline
\end{tabular}

\section{Copyrights}

Copyright for this article is retained by the author(s), with first publication rights granted to the journal.

This is an open-access article distributed under the terms and conditions of the Creative Commons Attribution license which permits unrestricted use, distribution, and reproduction in any medium, provided the original work is properly cited. 